\title{
Infection-Specific Activation of the Medicago truncatula Enod11 Early Nodulin Gene Promoter During Actinorhizal Root Nodulation
}

\author{
Sergio Svistoonoff, ${ }^{1}$ Mame-Ourèye Sy, ${ }^{1,2}$ Nathalie Diagne, ${ }^{1,3}$ David G. Barker, ${ }^{4}$ Didier Bogusz, ${ }^{1}$ and \\ Claudine Franche ${ }^{1}$ \\ ${ }^{1}$ Groupe Rhizogenèse, Unité Mixte de Recherche Diversité et Adaptation des Plantes Cultivées (DIAPC), Institut de \\ Recherche pour le Développement (IRD), 911 avenue Agropolis, BP 5045, 34394 Montpellier Cedex 5, France; ' 2 aboratoire \\ Campus de Biotechnologies Végétales, Département de Biologie Végétale, Faculté des Sciences et Techniques, Université \\ Cheikh Anta Diop, BP 5005, Dakar-Fann, Sénégal; ${ }^{3}$ Laboratoire Commun de Microbiologie IRD/ISRA/UCAD, Centre de \\ Recherche de Bel Air, BP 1386, Dakar, Sénégal; ${ }^{4}$ Laboratory of Plant-Microbe Interactions, UMR INRA/CNRS (441/2594), \\ Chemin de Borde-Rouge, Auzeville, BP 52627, 31326 Castanet-Tolosan Cedex, France
}

Submitted 25 November 2009. Accepted 17 February 2010.

The MtEnod11 gene from Medicago truncatula is widely used as an early infection-related molecular marker for endosymbiotic associations involving both rhizobia and arbuscular mycorrhizal fungi. In this article, heterologous expression of the MtEnod11 promoter has been studied in two actinorhizal trees, Casuarina glauca and Allocasuarina verticillata. Transgenic $C$. glauca and $A$. verticillata expressing a ProMtEnod11:: $\beta$-glucuronidase (gus) fusion were generated and the activation of the transgene investigated in the context of the symbiotic associations with the N-fixing actinomycete Frankia and both endo- and ectomycorrhizal fungi (Glomus intraradices and Pisolithus albus, respectively). ProMtEnod11::gus expression was observed in root hairs, prenodules, and nodules and could be correlated with the infection of plant cells by Frankia spp. However, no activation of the gus reporter gene was detected prior to infection or in response to either rhizobial Nod factors or the wasp venom peptide MAS-7. Equally, ProMtEnod11::gus expression was not elicited during the symbiotic associations with either ecto- or endomycorrhizal fungi. These observations suggest that, although there is a conservation of gene regulatory pathways between legumes and actinorhizal plants in cells accommodating endosymbiotic N-fixing bacteria, the events preceding bacterial infection or related to mycorrhization appear to be less conserved.

The adaptation of plants to nitrogen limitation often involves associations with diazotrophic soil bacteria. Most of these associations are loose and, even when bacteria penetrate the roots, they remain in the extracellular spaces. One remarkable exception involves plants belonging to the Fabid clade that are able to form new organs known as nodules, in which the bacteria are hosted intracellularly. The best-known of these symbioses are the interactions between legumes and a range of gramnegative bacteria collectively termed rhizobia. However, a second category of important root nodule symbioses, the so-called

Corresponding author: S. Svistoonoff; E-mail: sergio.svistoonoff@ird.fr

* The $\boldsymbol{e}$-Xtra logo stands for "electronic extra" and indicates that two supplementary figures are published online. actinorhizal symbioses, have been much less studied. These interactions involve more than 220 plant species from the other three Fabid orders (Rosales, Fagales, and Cucurbitales) that are nodulated by the gram-positive actinomycete Frankia (Vessey et al. 2004).

Two closely related actinorhizal trees, Casuarina glauca and Allocasuarina verticillata, are currently being used in our laboratory to study the molecular basis of the actinorhizal symbiosis. In members of Casuarinaceae, as in most legumes, bacteria are internalized through curled root hairs and form infection threads (IT). This is followed by cell divisions in the root cortex in the vicinity of the infected root hair, which give rise to a so-called prenodule. Prenodules are colonized by Frankia spp. and can even fix nitrogen but they do not develop further (Laplaze et al. 2000). Instead, cell divisions are induced in the root pericycle, leading to the formation of nodular lobes whose cortex is then colonized by Frankia spp.-containing IT. Nodules, the mature nitrogen-fixing organs, comprise several lobes, each representing a modified lateral root (Vessey et al. 2004).

Symbiotic associations in legumes involve signal exchange enabling mutual recognition. In the case of the rhizobial association, lipo-chitooligosacharides termed Nod factors (NF) play a crucial role. It is believed that their binding to specific plant receptors activates a signaling cascade involving the generation of a sustained intracellular calcium oscillatory response and depends on several key proteins, including putative receptor-like kinases containing either LysM motifs (NFP/NFR1/ NFR5) or LLR repeats (DMI2/SYMRK), putative ion channels (DMI1/CASTOR/POLLUX), a calcium and calmodulin-dependent protein kinase (DMI3/CCaMK), and several transcriptional regulators (NSP1/NSP2/Ets2/ERN). The activation of this NF-signaling pathway results in the expression of a specific set of genes involved in the symbiotic developmental program (Oldroyd and Downie 2008). Interestingly, mutants defective in certain genes involved in the NF-signaling pathway (e.g., DMI1, DMI2, and DMI3 in Medicago truncatula) are also affected in their ability to establish the symbiotic association with arbuscular-mycorrhizal fungi (AMF) (Catoira et al. 2000). Therefore, these particular components of the NF pathway are required for both types of endosymbiosis and are assumed to be part of an ancient symbiotic pathway involved in the accommodation of microbes by the plant cell (Kistner and Parniske 2002). 
The M. truncatula MtEnod11 gene is one of the earliest genes expressed in the root epidermis following initial contact with Sinorhizobium meliloti (Journet et al. 2001; Charron et al. 2004). MtEnod11 encodes a putative cell wall repetitive (hydroxy)-proline-rich protein and has been widely used as a marker for early infection-related symbiotic events. MtEnod11 expression in the $M$. truncatula epidermis initially occurs within the first hours following inoculation with $S$. meliloti (Boisson-Dernier et al. 2001; Journet et al. 2001). This early induction of MtEnodll by rhizobia can be mimicked by the addition of purified NF (Charron et al. 2004). This gene activation is dependent upon genes of the NF signal transduction pathway (Catoira et al. 2000; Charron et al. 2004). MtEnod11 is also expressed at later stages, when it is specifically associated with rhizobial infection in either root hairs or the infection zone of young nodules (Journet et al. 2001). Because MtEnod11 is also transcribed in M. truncatula roots during endomycorrhizal infection in epidermal and cortical cells containing penetration hyphae and in arbuscule-containing cells of the inner cortex, this gene has become a very useful marker for studying the initial developmental stages of both symbioses (Journet et al. 2001; Chabaud et al. 2002).

We recently reported that at least part of the common symbiotic pathway is also necessary for the successful development of actinorhizal symbioses because silencing of the $C$. glauca $C g S y m R K$ gene, the ortholog of $D M I 2 / L j S y m R K$, results in poor nodulation, nitrogen fixation, and mycorrhization. Therefore, we concluded that the developmental programs leading to the establishment of mycorrhiza as well as actinorhizal and rhizobial root nodule symbiosis share common signal transduction mechanisms (Gherbi et al. 2008).

To further investigate the evolutionary relationships between the three major endosymbioses, as well as the possibility of using MtEnod11 as a marker to identify potential Frankia spp. signaling molecules, we introduced the chimeric ProMtEnod11: : $\beta$-glucuronidase (gus) reporter gene into both $C$. glauca and A. verticillata. The patterns of nonsymbiotic and symbiotic activation were compared with the homologous activation of the same promoter in M. truncatula. Our results show that the activation of ProMtEnod11::gus in cells infected by symbiotic bacteria is conserved in actinorhizal plants, whereas this is not the case for the NF-dependent preinfection expression. Finally, our experiments show that ProMtEnod11::gus expression is not induced during either endo- or ectomycorhizal root colonization.

\section{RESULTS}

\section{ProMtEnod11::gus expression in nonsymbiotic tissues of transgenic $C$. glauca and $A$. verticillata.}

In all, 20 independent transgenic calli resistant to kanamycin were obtained via Agrobacterium tumefaciens-mediated transformation for both Allocasuarina verticillata and C. glauca. GUS activity was observed in most calli from both species (data not shown) and successful shooting was obtained for five calli of A. verticillata and six calli of $C$. glauca. Whole plants were regenerated and the resulting transgenic lines tested for gus expression (Fig. 1; Supplementary Fig. S1). For both species, GUS activity was detected in the columella root cap (Fig. $1 \mathrm{~A})$, mostly in primary or lateral roots that were actively growing. Short lateral roots that had stopped growing did not show any blue staining at the root tip (Fig. 1B). GUS activity was also detected in the vasculature of primary roots (Fig. 1C) and at the base of lateral roots (Fig. 1D). This expression pattern is reminiscent of that reported for the same construct in $M$. truncatula (Journet et al. 2001). In A. verticillata, strong GUS activity was also detected in the vasculature of shoots and in the epidermis, stomatal guard cells, and neighboring epidermal cells. In $C$. glauca, gus expression in shoots was barely detectable (data not shown).

\section{The MtEnod11 promoter is activated during plant cell infection by Frankia spp.}

Transgenic C. glauca and A. verticillata were inoculated with Frankia spp. and gus expression was analyzed at different times ranging from $3 \mathrm{~h}$ to 30 days after inoculation (DAI). Root hair deformation was observed 24 to $48 \mathrm{~h}$ after inoculation but no GUS activity was observed in epidermal tissues at this stage (Fig. 1E). On the other hand, from three DAI onward, GUS activity was detectable in a small number of root hairs that often showed the characteristic "shepherd's crook" curling at the tip (Fig. 1F through $\mathrm{H}$ ). As infection proceeded into the cortex, ProMtEnod11::gus expression also progressed to adjacent and underlying cells (Fig. H through J). The presence of IT suggests that transgene expression is directly linked to the infection of the host cells by Frankia spp. (Fig. 1H). At later stages, cortical cell divisions gave rise to prenodules where GUS activity could clearly be detected in Frankia spp.infected cells (Fig. 1J through L). The first nodules appeared at $20 \mathrm{DAI}$, and strong gus expression was observed in cells infected by Frankia spp. These cells were usually aligned, forming rows that spread from the base to the center of the nodule (Fig. 1M). To examine the transcriptional activation of ProMtEnod11::gus in more detail, we prepared semithin sections from mature $C$. glauca nodules (Fig $1 \mathrm{~N}$ through $\mathrm{P}$ and R). Adjacent sections were stained with toluidine blue to visualize the presence of Frankia spp. (Fig. 1O). In these sections, GUS activity was detected in Frankia spp.-infected cells but also in cells closer to the vascular bundle and the nodule tip where Frankia filaments were not detectable (Fig $1 \mathrm{~N}$ and O, arrows). Expression of gus in cells infected by Frankia spp. was often associated with the presence of IT (Fig. 1P).

To better understand the significance of this pattern of gus expression, we visualized the strong autofluorescence of the lignified cell walls associated with cell differentiation and nitrogen fixation using UV light (Berg and McDowell 1988). Autofluorescence was detected in the periderm, in the vascular tissues, and at the base of nodular lobes in infected cells corresponding to the nitrogen fixation zone. GUS activity was only detectable in a fraction of these cells, mostly corresponding to the transition between the infection zone and the fixation zone, in addition to those cells lacking a fluorescent cell wall that belong to the infection zone (Fig. 1Q). Expression of gus was also detected in the phloem parenchyma of the vascular bundle (Fig. 1N and R). A very similar pattern of GUS activity was observed in Frankia spp.-inoculated roots of A. verticillata transformed with the same ProMtEnod11::gus construct. A common pattern of expression was detected for the 11 independent transgenic lines (10 plants tested per line) (data not shown). We conclude that ProMtEnod11::gus expression is conserved between $M$. truncatula and members of Casuarinaceae in host cells undergoing infection by endosymbiotic bacteria.

To determine whether the activation of ProMtEnod11 is dependent on Frankia strains, transgenic C. glauca plants were inoculated with the compatible strain $\mathrm{CcI} 3$ in parallel with two strains unable to nodulate $C$. glauca (ACN14 and BCU110501) and gus expression assays were performed at different times ranging from 24 h to 45 DAI (Supplementary Fig. S2). Root hair deformation was first visible 2 DAI with both non-nodulating strains but root hairs were much less deformed and fewer roots showed deformed root hairs compared with plants inoculated with $\mathrm{CcI} 3$. Similar results were obtained at later stages, except that root hair deformation was visible over a wider zone of the 
roots. At 45 DAI, nodules were present on roots of all the plants inoculated with the compatible strain, whereas neither nodules nor prenodules could be detected for plants inoculated with the incompatible strains. Although nonsymbiotic gus expression was observed for all roots, reporter gene activity associated with root hairs, prenodules, and nodules was only observed in plants inoculated with the compatible strain $\mathrm{CcI} 3$.

To examine in more detail the response of ProMtEnod11 during the early steps of the interaction, transgenic $C$. glauca plants were incubated with the supernatant of a $\mathrm{CcI} 3$ Frankia culture and gus expression was analyzed 1,2, and 7 days after the onset of the incubation. Extensive root hair deformation was observed in plants incubated with the supernatant, whereas control plants showed only limited root hair deformation. Despite the extensive root hair deformation, no GUS activity was detected in root hairs treated with the Frankia supernatant.

Taken together, these experiments reveal that the expression of ProMtEnod11::gus is only induced in Casuarina spp. in the context of the infection of host cells by a compatible Frankia strain.
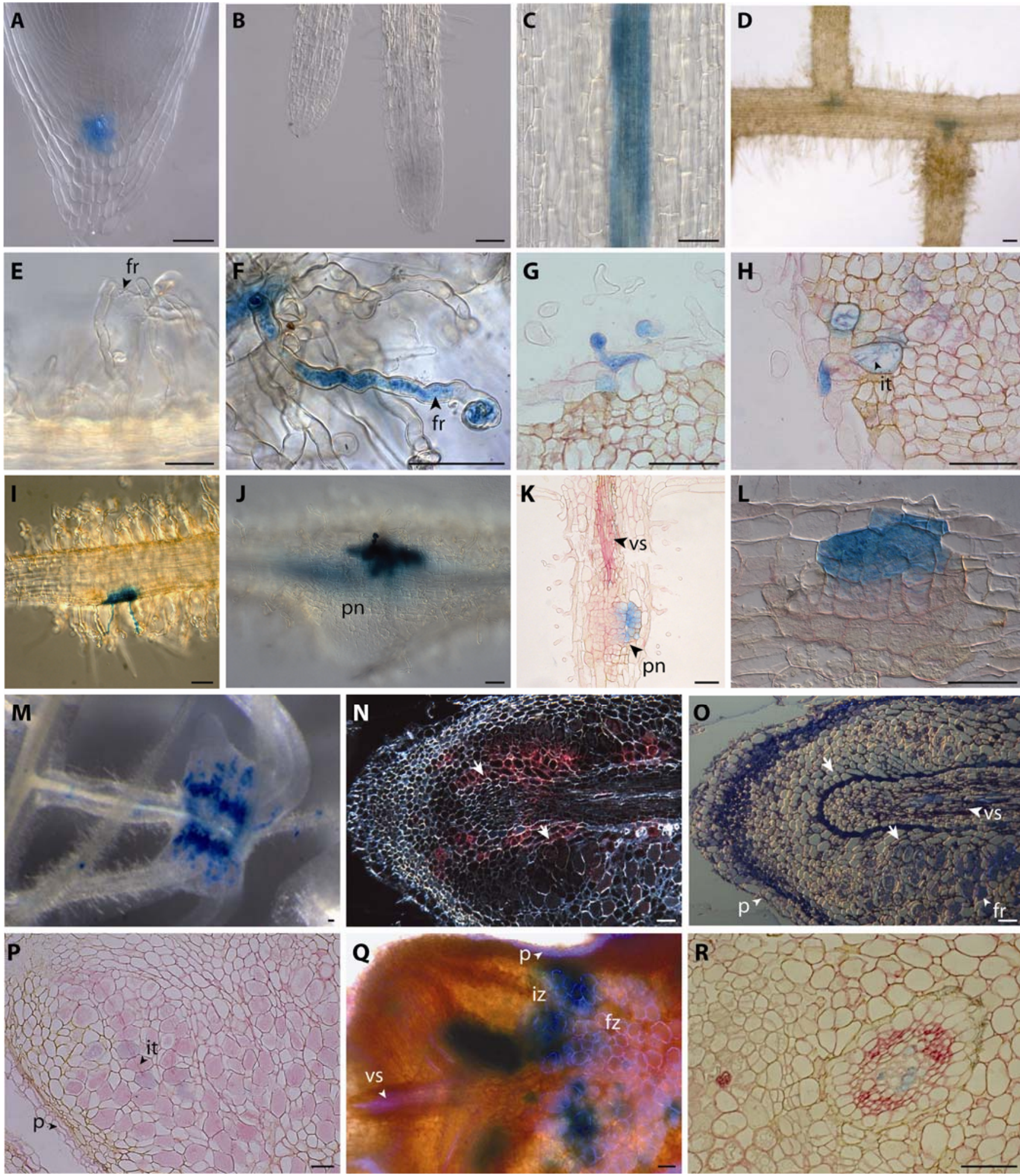


\section{NF and MAS-7 do not transcriptionally activate ProMtEnod11::gus in C. glauca.}

The MtEnodll promoter is strongly induced in the M. truncatula root epidermis in response to purified NF (Charron et al. 2004). In legumes, the putative receptor-like kinases NFP/ LYK3/NFR1/NFR5, containing extracellular LysM motifs, are excellent candidates for perceiving NF (Oldroyd and Downie 2008). A TBLASTN search performed on the $C$. glauca expressed sequence tag database (Hocher et al. 2006; unpublished results) revealed 21 sequences showing up to $67 \%$ similarity with these LysM-containing proteins (cutoff $e$ value: $10^{-30}$ ), suggesting that receptors for molecules similar in structure to NF might be present in the $C$. glauca genome. To investigate whether NF are able to activate ProMtEnod11::gus in $C$. glauca, transgenic plantlets were incubated with purified NF from either Sinorhizobium meliloti or from the broad-spectrum Rhizobium sp. strain NGR234. Transgenic M. truncatula roots carrying the same construct were used as a positive control for $S$. meliloti NF treatment (Fig. 2). Assuming that C. glauca receptors for Frankia NF-like signals would probably recognize rhizobial NF with low affinity, NF were applied at $10^{-7} \mathrm{M}$ instead of $10^{-9} \mathrm{M}$, the concentration usually employed to elicit strong MtEnod11 expression in M. truncatula roots (Charron et al. 2004). However, despite this high NF concentration, rhizobial NF failed to elicit either root hair deformation or reporter GUS activity in the transgenic C. glauca epidermis (Fig. 2). Therefore, these results suggest either that the $C$. glauca proteins similar to NFR5/NFR1/NFP do not recognize rhizobial NF or that the signal transduction pathway leading to root hair deformation and the activation of the MtEnodl1 promoter is not functional in the actinorhizal root epidermis.

In an attempt to discriminate between these two alternatives, we used a pharmacological approach based on mastoparan, an amphiphilic wasp venom peptide used widely in animal systems to activate $G$ protein-mediated signaling pathways. Although the cellular target for mastoparan has not yet been defined in plants, mastoparan or its more active form, MAS-7, has been shown to activate the Enod11 and Enod12 promoters in the absence of NF in both alfalfa and M. truncatula (Pingret et al. 1998; Charron et al. 2004) and to induce calcium spiking analogous to NF-induced responses in M. truncatula (Sun et al. 2007). In addition, the induction of ProMtEnod11::gus by MAS-7 in M. truncatula depends on the DMI3 gene but not on $D M I 1 / 2$, thus implying that MAS-7 acts downstream of DMI1/2. MAS-7 was applied to the roots of transgenic ProMtEnod11::gus C. glauca plants, again using M. truncatula as a positive control. As expected, treatment with $0.2 \mu \mathrm{M}$ MAS-7 resulted in clear GUS activity in the $M$. truncatula epidermis
(Charron et al. 2004) (Fig. 2). However, no epidermal GUS activity was detected in transgenic C. glauca roots (Fig. 2), suggesting either that the transduction pathway leading to ProMtEnod11::gus expression is not functional in the actinorhizal host or that MAS-7 is unable to activate its signal transduction target.

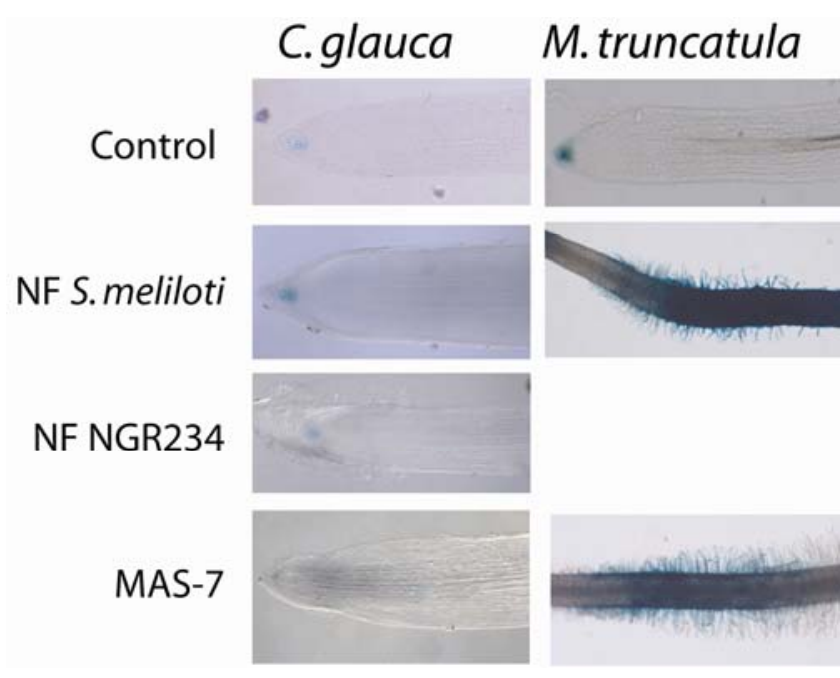

Fig. 2. Effect of incubation with rhizobial Nod factors (NF) or MAS-7 on the expression of ProMtEnod11:: $\beta$-glucuronidase (gus) in Casuarina glauca or Medicago truncatula. Roots were incubated for $8 \mathrm{~h}$ with NF from Sinorhizobium meliloti or Rhizobium sp. NGR234 at $0.1 \mu \mathrm{M}$ or with $0.2 \mu \mathrm{M}$ MAS-7. Roots were cleared with $\mathrm{KOH}$ after GUS staining.

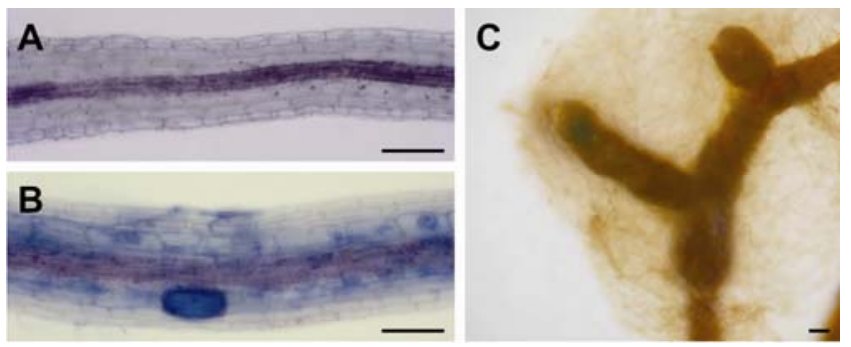

Fig 3. Analysis of ProMtEnod11:: $\beta$-glucuronidase (gus) expression upon mycorrhization. Magenta GUS/trypan blue staining of either A, noncolonized roots of Casuarina glauca or B, roots colonized by Glomus intraradices 6 weeks after inoculation. Background GUS activity is visible in the vascular system. C, Allocasuarina verticillata roots colonized by Pisolitus albus and stained for GUS activity. Reporter expression is not associated with the extensive ectomycorrhizal colonization. Bar $=100 \mu \mathrm{m}$.

Fig. 1. Histochemical localization of $\beta$-glucuronidase (GUS) activity in Casuarina glauca roots expressing the ProMtEnod11::gus construct. A through C, Noninoculated roots. A, Primary root showing GUS activity in the columella root cap; B, lateral roots that have stopped growing show no reporter activity at the root tips; C, strong gus expression in the vascular system of a primary root. D through R, Analysis of ProMtEnod11:: gus expression during early and late stages of actinorhizal infection/nodulation. D, Root inoculated with Frankia CcI3 2 days after inoculation (DAI) showing extensive root hair deformation and nonsymbiotic gus expression at the base of lateral roots. E, Root inoculated with Frankia CcI3 2 DAI. Frankia filaments and deformed root hairs were present but no GUS activity was detected in the epidermis. F through I, Roots inoculated with Frankia at 7 DAI show strong GUS activity in certain deformed root hairs often associated with the presence of Frankia filaments and infection threads. J through L, Cell divisions have generated prenodules and nodule primordia at 10 DAI. Intense GUS activity is still detected in root hairs and neighboring cells but has not spread to dividing cells. M through R, GUS activity in mature nodules at $30 \mathrm{DAI}$; M, whole nodule showing rows of cells strongly expressing GUS activity; N, longitudinal section of a nodule lobe with GUS activity visible in cortical cells and the vascular system; O, adjacent section to (N) stained with toluidine blue to visualize cells infected by Frankia. Arrows in N and O indicate cells without Frankia expressing gus. P, Detail of a longitudinal section of a nodule lobe with GUS activity visible in infected cells containing infection threads. Q, Thick section of a nodule lobe showing intense GUS activity in infected cells. Overlaid is the image of the same section observed under UV light to visualize the blue autofluorescence of the lignified cell walls of the periderm, vascular system, and infected cells belonging to the fixation zone. Expression of gus is mainly observed in nonlignified cells. In contrast, lignified cells located at the base of the nodule show little or no GUS activity. R, Transverse section of a mature nodule showing GUS activity in the phloem parenchyma. A, B, C, D, E, F, I, J, and M, Whole organs cleared with $\mathrm{KOH} ; \mathbf{G}, \mathbf{H}, \mathbf{K}, \mathbf{L}, \mathbf{Q}$, and $\mathbf{R}$, semithin sections stained with ruthenium red; $\mathbf{N}$, semithin section without any staining observed in dark field; $\mathbf{O}$, semithin section colored with toluidine blue; P, vibratome section. Abbreviations: fr, Frankia filaments; it, infection threads; pn, prenodule; vs, vascular system; p, periderm; iz, infection zone; fz, fixation zone. Bar $=50 \mu \mathrm{m}$. 
The MtENOD11 promoter is not activated during mycorrhizal colonization of $C$. glauca.

As discussed earlier, the MtEnod11 gene is strongly activated in arbuscule-containing cells of $M$. truncatula (Journet et al. 2001). To assess whether this is also the case in $C$. glauca, transgenic ProMtEnod11::gus plants were inoculated with Glomus intraradices and roots were harvested at 2, 4, and 6 weeks after inoculation to examine different stages of colonization. The first mycorrhizal structures could be seen 4 weeks after inoculation and, at 6 weeks, fungal hyphae forming vesicles and arbuscules were observed in most roots of inoculated plants. However, no GUS activity was associated with this endomycorrhizal colonization in the root inner cortex (Fig. 3A and B).

$A$. verticillata (but not $C$. glauca) can also establish a symbiotic association with ectomycorrhizal (ECM) fungi (Duponnois et al. 2003). To determine whether ectomycorrhization influences MtEnod11 promoter activity, transgenic A. verticillata plants expressing ProMtEnod11::gus were inoculated with the ECM fungus Pisolitus albus. Although a fungal mantle had developed on part of the root system 2 to 3 weeks later, no modifications in reporter gene expression were observed compared with noncolonized roots (Fig. 3C). Taken together, these results suggest that the MtEnod11 promoter is not activated during mycorrhizal symbioses in actinorhizal plants.

\section{Effect of lipid extracts from either Frankia spp. or C. glauca nodules on the activation of ProMtEnod11::gus.}

The fact that ProMtEnod11::gus activity appears to be specifically associated with Frankia spp. infection of Casuarina spp. roots suggests that promoter activation is linked to the physical presence of the endosymbiotic bacterium. In potato, it has been shown that a lipid molecule extracted from mycorrhizae, lyso-phosphatidyl choline, can activate the promoter of StPT3, a gene encoding a phosphate transporter expressed in arbuscule-containing cells (Rausch et al. 2001; Drissner et al. 2007). To investigate whether similar lipid molecules are able to activate the MtEnod11 promoter in C. glauca, lipids were extracted from both noninoculated roots and nodules of $C$. glauca, as well as from Frankia cells. Transgenic $C$. glauca plants were infiltrated with these extracts and GUS activity was examined. Although background nonsymbiotic GUS activity was detected in all roots, no modifications in the pattern of gus expression were observed between plants infiltrated with lipid extracts and control plants, suggesting that the lipid molecules obtained from Frankia spp. or nodules are not sufficient to elicit ProMtEnod11 activation.

\section{DISCUSSION}

The M. truncatula Enod11 promoter has been widely used as a marker for root endosymbioses because it is activated both in response to rhizobia and AMF during various stages of root infection and colonization. Here, we have investigated the activation pattern of the ProMtEnod11:: gus reporter in the roots of two actinorhizal trees, $C$. glauca and $A$. verticillata. Interestingly, ProMtEnod11 conserves its nonsymbiotic expression pattern in the root vasculature and in root caps of actively growing roots of transgenic $C$. glauca and A. verticillata, suggesting that the corresponding regulators of gene expression in these tissues are well conserved in actinorhizal plants.

In M. truncatula, MtEnod11 gene expression is correlated with both preinfection and infection events throughout nodulation (Journet et al. 2001). In the two actinorhizal species studied here, we have observed activation of the ProMtEnod11:: gus reporter correlating with Frankia infection in root hairs, prenodules, and nodules. In nodules, high levels of GUS activity were detected in cells within the infection zone which con- tain Frankia spp. but lack a fluorescent cell wall (Berg and McDowell 1988), and also in surrounding cells, suggesting a link between pMtEnod11 activation and bacterial infection. However, in the absence of a reliable method to specifically label Frankia spp. with protein reporters, it is not possible to establish a strict correlation between GUS activity and the presence of Frankia spp.

As opposed to M. truncatula, GUS activity was also detected in noninfected cells of the vascular system of $C$. glauca nodules. Actinorhizal nodules are very similar to lateral roots because both organs originate from cell divisions in the pericycle and share the same anatomical features, including a central vascular bundle. Therefore, the activation of ProMtEnod11:: gus in the nodule vascular system of $C$. glauca is probably related to the nonsymbiotic expression observed in the root vasculature.

Whereas MtEnod11 is first expressed in the M. truncatula epidermis 3 to $6 \mathrm{~h}$ after inoculation with $S$. meliloti (Journet et al. 2001), ProMtEnod11 is not activated in transgenic Casuarinaceae spp. prior to infection. Furthermore, we were unable to induce ProMtEnod11::gus in the C. glauca epidermis using Frankia supernatants, incompatible Frankia strains, or purified NF. Taken together, these results suggest that transcriptional upregulation of this promoter preceding microbial infection is not conserved in $C$. glauca. A deletion analysis performed on the promoter of MtEnod11 has identified two distinct regulatory regions. The first region, the so-called "Nod box", positioned at -391 to -358 upstream of the initiation codon, is responsible for expression in the $M$. truncatula epidermis in response to NF and prior to infection (Andriankaja et al. 2007). The second region, corresponding to the 257-bp sequence upstream of the initiation codon, is responsible for expression during endosymbiotic infection as well as in lateral root primordia (Boisson-Dernier et al. 2005; Andriankaja et al. 2007). Our results suggest that only the infection region is recognized in Casuarinaceae spp., and experiments using ProMtEnod11 deletions are currently underway to test this hypothesis. This conclusion is also consistent with the failure to activate ProMtEnod11::gus expression in C. glauca with the MAS-7 peptide, which is able to mimic NF activity in $M$. truncatula (Charron et al. 2004).

MtEnod11 is considered an early-expressed marker gene for both root endosymbioses in $M$. truncatula because it is activated not only in response to rhizobia but also during various stages of the interaction with endomycorrhizal fungi (Chabaud et al. 2002). AMF can also activate ProMtEnod11:: gus even when the plant is separated from the fungus by a membrane; however, this activation is mediated by a diffusible signal that does not depend on the DMI1, DMI2, or DMI3 genes (Kosuta et al. 2003). Boisson-Dernier and associates (2005) have shown that the infection region of the MtEnod11 promoter is sufficient for expression in M. truncatula during arbuscule formation, and rhizobial infectionrelated expression is well conserved between $C$. glauca and M. truncatula; therefore, we had expected that AMF colonization in C. glauca would be associated with ProMtEnod11:: gus activation. However, our results show that this is not the case and, indeed, carrot roots transformed with the same construct also failed to show GUS activity in response to AM colonization (Genre et al. 2008). This suggests that the molecular mechanisms leading to the activation of ProMtEnod11 in response to AMF are less conserved than those involved in the root nodule symbiosis. Finally, we also examined whether ProMtEnod11::gus could be activated in A. verticillata in response to colonization by the ectomycorrhizal fungus $P$. albus. Again, fungal colonization was not accompanied by transcriptional activation of the ProMtEnod11::gus reporter. 
However, bearing in mind that ectomycorrhizal colonization does not involve intracellular accommodation of the symbiont, this negative result is probably not surprising.

The expression pattern of ProMtEnod11::gus in nodules of Casuarinaceae spp. is similar to that conferred by the promoter of PsEnod12b, another early nodulin from Pisum sativum also encoding a repetitive proline-rich protein (Sy et al. 2006). Like ProMtEnod11, ProPsEnod12B drives gus expression in cells infected by Frankia spp. near the nodule apex but not in fully differentiated cells located at the base of the nodule (Sy et al. 2006). The fact that ProPsEnod12:: gus activation was not detected during earlier epidermal or cortical infection may be due to a lower expression level for the $P s$ Enod $12 b$ promoter. Two $C$. glauca promoters show similar expression patterns compared with ProMtEnod11::gus. The $C g A U X 1$ promoter is activated in root tips, the root vasculature, and during Frankia spp. infection (Péret et al. 2007), and the $C g 12$ promoter is specifically activated during plant cell infection by Frankia spp. (Svistoonoff et al. 2003). Interestingly, neither of these C. glauca promoters are activated by AMF (Svistoonoff et al. 2003; Péret et al. 2008) and they both retain their tissue-specific expression patterns when introduced into M. truncatula (Svistoonoff et al. 2004; unpublished results). Conserved transcriptional regulation has also been observed for genes encoding hemoglobins that are involved during later stages of the $\mathrm{N}_{2}$-fixing symbiotic association: the soybean (Glycine max) Lbc3 gene retains its cell specificity in transgenic A. verticillata (Franche et al. 1998), as does the C. glauca promoter in transgenic Lotus japonicus (JacobsenLyon et al. 1995). Taken together, these results suggest a high conservation of gene regulatory pathways between legumes and actinorhizal plants in cells involved in bacterial infection and accommodation.

The capacity of the plant to accommodate $\mathrm{N}_{2}$-fixing bacteria intracellularly is considered to be a key event in the evolution of root nodule symbiosis (Kistner and Parniske 2002) and is a unifying feature of all root nodule symbiosis. Using molecular markers of bacterial infection such as MtEnod11, $\mathrm{Cg} 12$, or $C g A U X 1$, it may now be possible to isolate signaling molecules directly involved in the establishment of intracellular accommodation of symbiotic bacteria by plant cells.

\section{MATERIALS AND METHODS}

\section{Plant material and bacterial strains.}

C. glauca and A. verticillata seeds were purchased from Carter Seeds (Vista, CA, U.S.A.) and the Versepuy Company (Le Puy en Velay, France), respectively, and grown for transformation as described by Sy and associates (2006). M. truncatula transgenic line L416, containing the 2.3-kb 5' upstream region of the MtEnod11 gene fused to gus (ProMtEnod11:: gus), is described by Charron and associates (2004). Agrobacterium tumefaciens-mediated transformation of $C$. glauca was performed using the strain C58C1 (pGV2260) (Vancanneyt et al. 1990). The Frankia strains CcI3 (Normand et al. 2007) and Allo2 (Benoist et al. 1992) were used to nodulate C. glauca and Allocasuarina verticillata, respectively. Frankia strains ACN14, isolated from Alnus spp. (Normand et al. 2007) and BCU110501, isolated from Discaria spp. (Chaia 1998), were used to test the effect of incompatible strains on C. glauca. The starting cultures of Glomus intraradices DAOM 197198 were provided by G. Bécard (Cell Surfaces and Plant Signalling, UMR CNRS-Paul Sabatier University, Toulouse, France). Ectomycorrhization experiments were performed using the Pisolitus albus IR100 strain provided by R. Duponnois (Laboratoire Commun de Microbiologie, Dakar, Senegal).

\section{Genetic transformation.}

Stable transformation of both A. verticillata and C. glauca were performed using Agrobacterium tumefaciens carrying the ProMtEnod11::gus construct as described by Franche and associates (1997) and Sy and associates (2006).

\section{Nodulation and mycorrhization experiments.}

A. verticillata nodulation was performed as reported by Sy and associates (2006). For C. glauca nodulation, plants obtained in vitro as described by Franche and associates (1997) were transferred to a hydroponic system consisting of plastic pots (approximately 1 liter) filled with 0.75 liter of a modified Broughton and Dillworth (BD) nutrient solution ( $5 \mathrm{mM} \mathrm{KNO}_{3}$, $1 \mathrm{mM} \mathrm{CaCl}_{2}, 0.5 \mathrm{mM} \mathrm{KH} \mathrm{PO}_{4}, 0.25 \mathrm{mM} \mathrm{MgSO} 4,0.25 \mathrm{mM}$ $\mathrm{K}_{2} \mathrm{SO}_{4}, 1 \mathrm{mM} \mathrm{MnSO}{ }_{4}, 25 \mu \mathrm{M} \mathrm{Na}{ }_{2}$ EDTA, $25 \mu \mathrm{M} \mathrm{FeSO}_{4}, 2 \mu \mathrm{M}$ $\mathrm{H}_{3} \mathrm{BO}_{3}, 0.5 \mu \mathrm{M} \mathrm{ZuSO}, 0.2 \mu \mathrm{M} \mathrm{CuSO}_{4}, 0.1 \mu \mathrm{M} \mathrm{CoSO}_{4}$, and $0.1 \mu \mathrm{M} \mathrm{Na}{ }_{2} \mathrm{MoO}_{4}$ ). Pots were covered with plastic lids with 4 holes through which the plantlets were introduced. Plants were maintained in place with polystyrene rings. To multiply plants vegetatively, 4- to 5-cm-long shoot segments were excised and immersed in $10 \mu \mathrm{M}$ indole-3-butyric acid to induce root formation. After $24 \mathrm{~h}$, the segments were transferred to the hydroponic system described above. After 3 to 5 weeks, plants with well-developed roots (total root length $>20 \mathrm{~cm}$ ) and shoots (total shoot length $>10 \mathrm{~cm}$ ) were transferred to a nitrogen-free Broughton and Dillworth nutrient solution for 1 week and inoculated with Frankia spp. as described by Franche and associates (1997). Inoculated plants were maintained in the hydroponic system with nitrogen-free BD media for 6 to 8 weeks. Comparative experiments using strains from Alnus (ACN14) and Discaria (BCU110501) were carried on C. glauca as above. Control plants were inoculated with nitrogen-free nutrient media. The experiment was carried on four plants per treatment and was repeated twice.

Mycorrhization assays of $C$. glauca and $A$. verticillata were performed with $G$. intraradices and $P$. albus as described by Svistoonoff and associates (2003) and Gherbi and associates (2008).

\section{Treatment with Frankia supernatants, purified NF, and MAS-7.}

Frankia supernatants were prepared from a Frankia $\mathrm{CcI} 3$ culture by pelleting cells by centrifugation as described (Franche et al. 1997). The supernatant was filtrated through a $0.2-\mu \mathrm{m}$ filter. Transgenic $C$. glauca and $M$. truncatula plants were cultivated in the hydroponic system with BD medium and in petri dishes containing Fahareus medium as described by Svistoonoff and associates (2004), respectively. Plants were transferred to a nitrogen-free medium either for 1 week (C. glauca) or 2 days (M. truncatula). For the Frankia supernatant experiments, four plants were transferred to a plastic tray and roots were incubated for $8 \mathrm{~h}$ with $10 \mathrm{ml}$ of Frankia supernatant diluted in $90 \mathrm{ml}$ of nitrogen-free nutrient solution. Control treatments were performed using the nutrient solution alone or with a 1:9 dilution of the Frankia growth media. Roots were then removed and stained to detect GUS activity. The experiment was repeated twice using four plants for each treatment.

For NF and MAS-7 experiments, plants were transferred into 24-well plates, where roots were incubated for $8 \mathrm{~h}$ in morpholineethanesulfonic acid (MES) buffer containing $0.1 \mu \mathrm{M}$ NF from $S$. meliloti or $0.2 \mu$ M MAS-7 (Pingret et al. 1998). Control plants were incubated in MES buffer. $C$. glauca plantlets were also incubated in MES buffer containing $0.1 \mu \mathrm{M}$ NGR234 NF. Roots were then removed and stained to detect GUS activity. At least three plants were used for each treatment and the experiments were repeated twice. 


\section{Lipid extracts and treatments.}

Total lipids were extracted from 1 to $2 \mathrm{~g}$ fresh weight of noninoculated $C$. glauca roots, nodules, or Frankia spp. with a chloroform-methanol-citrate buffer and dissolved in methanol as described by Drissner and associates (2007). Transgenic $C$. glauca plants deprived of nitrogen for 1 week were infiltrated for 3 min with 1:10 aqueous dilutions of the extracts using a vacuum pump. Control experiments included a 1:10 methanol solution and water. Plants were then transferred to an $\mathrm{N}$-free $\mathrm{BD}$ medium for $3 \mathrm{~h}$ and assayed for GUS activity. The experiment was performed on at least four plants per treatment and was repeated twice.

\section{Histochemical GUS assays and microscopy.}

Sectioning of plant material and GUS assays using GlcA (5bromo-4-chloro-3-indoxyl- $\beta$-D-glucuronic acid cyclohexylammonium salt [Duchefa Biochemie BV, Haarlem, The Netherlands]) were performed as described by Svistoonoff and associates (2003) and Péret and associates (2007). Semithin sections were stained with toluidine blue $(0.01 \%)$ or ruthenium red $(0.05 \%)$, and mounted in Clearium mountant (Surgipath, Richmond, IL, U.S.A.). GUS-stained samples were also observed after clearing the tissues for 12 to $36 \mathrm{~h}$ in $10 \% \mathrm{KOH}$ at $90^{\circ} \mathrm{C}$. For mycorrhizal samples, Magenta-GlcA (Duchefa Biochemie BV) was used instead of GlcA in order to obtain contrasting red GUS staining. AM structures were viewed following the GUS assay as described by Diouf and associates (1995) and Gherbi and associates (2008). Samples were viewed under a DMRB (Leica, Wetzlar, Germany) and an AX10 (Zeiss, Oberkochen, Germany) microscope using brightfield-darkfield differential interference contrast and fluorescence microscopy, and images were acquired using a DFC300FX (Leica) or an MP5 (Qimaging, Surrey, BC, Canada) digital camera.

\section{ACKNOWLEDGMENTS}

We thank L. Wall and P. Normand for providing the BCU110501 and the ACN14 strains; J. Dénarié for providing Nod factors from $S$. meliloti and NGR234; R. Duponnois for providing IR100; G. Bécard for providing G. intraradices starting cultures; M. Collin, D. Moukouanga, V. Vaissayre, and J. Bonneau for help with histological work and transformation of $C$. glauca; L. Laplaze for his critical reading of the manuscript; and F. de Carvalho-Niebel for helpful discussions. This work was funded by the IRD and grants from the Agence Nationale de la Recherche (ANR-08JCJC-0070-01) and Agence Universitaire de la Francophonie.

\section{LITERATURE CITED}

Andriankaja, A., Boisson-Dernier, A., Frances, L., Sauviac, L., Jauneau, A., Barker, D. G., and de Carvalho-Niebel, F. 2007. AP2-ERF transcription factors mediate Nod factor dependent MtENOD11 activation in root hairs via a novel cis-regulatory motif. Plant Cell 19:2866-2885.

Benoist, P., Muller, A., Diem, H. G., and Schwencke, J. 1992. High-molecular-mass multicatalytic proteinase complexes produced by the nitrogenfixing actinomycete Frankia strain BR. J. Bacteriol. 174:1495-1504.

Berg, R. H., and McDowell, L. 1988. Cytochemistry of the wall of infected cells in Casuarina actinorhizae. Can. J. Bot. 66:2038-2047.

Boisson-Dernier, A., Chabaud, M., Garcia, F., Bécard, G., Rosenberg, C., and Barker, D. G. 2001. Agrobacterium rhizogenes-transformed roots of Medicago truncatula for the study of nitrogen-fixing and endomycorrhizal symbiotic associations. Mol. Plant-Microbe Interact. 14:695700

Boisson-Dernier, A., Andriankaja, A., Chabaud, M., Niebel, A., Journet, E. P., Barker, D. G., and de Carvalho-Niebel, F. 2005. MtENOD11 gene activation during rhizobial infection and mycorrhizal arbuscule development requires a common AT-rich-containing regulatory sequence. Mol. Plant-Microbe Interact. 18:1269-1276.

Catoira, R., Galera, C., de Billy, F., Penmetsa, R. V., Journet, E. P., Maillet, F., Rosenberg, C., Cook, D., Gough, C., and Denarié, J. 2000. Four genes of Medicago truncatula controlling components of a nod factor transduction pathway. Plant Cell 12:1647-1665.
Chabaud, M., Venard, C., Defaux-Petras, A., Bécard, G., and Barker, D. G. 2002. Targeted inoculation of Medicago truncatula in vitro root cultures reveals MtENOD11 expression during early stages of infection by arbuscular mycorrhizal fungi. New Phytol. 156:265-273.

Chaia, E. 1998. Isolation of an effective strain of Frankia from nodules of Discaria trinervis (Rhamnaceae). Plant Soil 205:99-102.

Charron, D., Pingret, J. L., Chabaud, M., Journet, E. P., and Barker, D. G. 2004. Pharmacological evidence that multiple phospholipid signaling pathways link Rhizobium nodulation factor perception in Medicago truncatula root hairs to intracellular responses, including $\mathrm{Ca} 2+$ spiking and specific ENOD gene expression. Plant Physiol. 136:3582-3593.

Diouf, D., Gherbi, H., Prin, Y., Franche, C., Duhoux, E., and Bogusz, D. 1995. Hairy root nodulation of Casuarina glauca: A system for the study of symbiotic gene expression in an actinorhizal tree. Mol. PlantMicrobe Interact. 8:532-537.

Drissner, D., Kunze, G., Callewaert, N., Gehrig, P., Tamasloukht, M., Boller, T., Felix, G., Amrhein, N., and Bucher, M. 2007. Lyso-phosphatidylcholine is a signal in the arbuscular mycorrhizal symbiosis. Science 318:265-268

Duponnois, R., Diedhiou, S., Chotte, J. L., and Sy, M. O. 2003. Relative importance of the endomycorrhizal and (or) ectomycorrhizal associations in Allocasuarina and Casuarina genera. Can. J. Bot. 49:281-287.

Franche, C., Diouf, D., Le, Q. V., Bogusz, D., N'Diaye, A., Gherbi, H., Gobé, C., and Duhoux, E. 1997. Genetic transformation of the actinorhizal tree Allocasuarina verticillata by Agrobacterium tumefaciens. Plant J. 11:897-904.

Franche, C., Diouf, D., Laplaze, L., Auguy, F., Frutz, T., Rio, M., Duhoux, E., and Bogusz, D. 1998. Soybean(lbc 3), Parasponia, and Trema hemoglobin gene promoters retain symbiotic and nonsymbiotic specificity in transgenic Casuarinaceae: Implications for hemoglobin gene evolution and root nodule symbioses. Mol. Plant-Microbe Interact. 11:887-894.

Genre, A., Chabaud, M., Faccio, A., Barker, D. G., and Bonfante, P. 2008. Prepenetration apparatus assembly precedes and predicts the colonization patterns of arbuscular mycorrhizal fungi within the root cortex of both Medicago truncatula and Daucus carota. Plant Cell 20:1407-1420.

Gherbi, H., Markmann, K., Svistoonoff, S., Estevan, J., Autran, D., Giczey, G., Auguy, F., Péret, B., Laplaze, L., Franche, C., Parniske, M., and Bogusz, D. 2008. SymRK defines a common genetic basis for plant root endosymbioses with AM fungi, rhizobia and Frankia bacteria. Proc. Natl. Acad. Sci. U.S.A. 105:4928-4932.

Hocher, V., Auguy, F., Argout, X., Laplaze, L., Franche, C., and Bogusz, D. 2006. Expressed sequence-tag analysis in Casuarina glauca actinorhizal nodule and root. New Phytol. 169:681-688.

Jacobsen-Lyon, K., Jensen, E. O., Jorgensen, J. E., Marcker, K. A., Peacock, W. J., and Dennis, E. S. 1995. Symbiotic and nonsymbiotic hemoglobin genes of Casuarina glauca. Plant Cell 7:213-223.

Journet, E. P., El-Gachtouli, N., Vernoud, V., de Billy, F., Pichon, M., Dedieu, A., Arnould, C., Morandi, D., Barker, D. G., and Gianinazzi-Pearson, V. 2001. Medicago truncatula ENOD11: A novel RPRP-encoding early nodulin gene expressed during mycorrhization in arbuscule-containing cells. Mol. Plant-Microbe Interact. 14:737-748.

Kistner, C., and Parniske, M. 2002. Evolution of signal transduction in intracellular symbiosis. Trends Plant Sci. 7:511-518.

Kosuta, S., Chabaud, M., Lougnon, G., Gough, C., Denarié, J., Barker, D. G., and Bécard, G. 2003. A diffusible factor from arbuscular mycorrhizal fungi induces symbiosis-specific MtENOD11 expression in roots of Medicago truncatula. Plant Physiol. 131:952-962.

Laplaze, L., Duhoux, E., Franche, C., Frutz, T., Svistoonoff, S., Bisseling, T., Bogusz, D., and Pawlowski, K. 2000. Casuarina glauca prenodule cells display the same differentiation as the corresponding nodule cells. Mol. Plant-Microbe Interact. 13:107-112.

Normand, P., Lapierre, P., Tisa, L. S., Gogarten, J. P., Alloisio, N., Bagnarol, E., Bassi, C. A., Berry, A. M., Bickhart, D. M., Choisne, N., Couloux, A., Cournoyer, B., Cruveiller, S., Daubin, V., Demange, N., Francino, M. P., Goltsman, E., Huang, Y., Kopp, O. R., Labarre, L., Lapidus, A., Lavire, C., Marechal, J., Martinez, M., Mastronunzio, J. E., Mullin, B. C., Niemann, J., Pujic, P., Rawnsley, T., Rouy, Z., Schenowitz, C., Sellstedt, A., Tavares, F., Tomkins, J. P., Vallenet, D., Valverde, C., Wall, L. G., Wang, Y., Medigue, C., and Benson, D. R. 2007. Genome characteristics of facultatively symbiotic Frankia sp. strains reflect host range and host plant biogeography. Genome Res. 17:7-15.

Oldroyd, G. E., and Downie, J. A. 2008. Coordinating nodule morphogenesis with rhizobial infection in legumes. Annu. Rev. Plant Biol. 59:519-546.

Péret, B., Swarup, R., Jansen, L., Devos, G., Auguy, F., Collin, M., Santi, C., Hocher, V., Franche, C., Bogusz, D., Bennett, M., and Laplaze, L. 2007. Auxin influx activity is associated with Frankia infection during actinorhizal nodule formation in Casuarina glauca. Plant Physiol. 144:1852-1862. 
Péret, B., Svistoonoff, S., Lahouze, B., Auguy, F., Santi, C., Doumas, P., and Laplaze, L. 2008. A role for auxin during actinorhizal symbioses formation? Plant Signal. Behav. 3:34-35.

Pingret, J. L., Journet, E. P., and Barker, D. G. 1998. Rhizobium nod factor signaling. Evidence for a g protein-mediated transduction mechanism. Plant Cell 10:659-672.

Rausch, C., Daram, P., Brunner, S., Jansa, J., Lalol, M., Leggewie, G., Amrhein, N., and Bucher, M. 2001. A phosphate transporter expressed in arbuscule-containing cells in potato. Nature 414:462-466.

Sun, J., Miwa, H., Downie, J. A., and Oldroyd, G. E. 2007. Mastoparan activates calcium spiking analogous to Nod factor-induced responses in Medicago truncatula root hair cells. Plant Physiol. 144:695-702.

Svistoonoff, S., Laplaze, L., Auguy, F., Runions, J., Duponnois, R., Haseloff, J., Franche, C., and Bogusz, D. 2003. cg12 expression is specifically linked to infection of root hairs and cortical cells during Casuarina glauca and Allocasuarina verticillata actinorhizal nodule development. Mol. Plant-Microbe Interact. 16:600-607.
Svistoonoff, S., Laplaze, L., Liang, J., Ribeiro, A., Gouveia, M. C., Auguy, F., Fevereiro, P., Franche, C., and Bogusz, D. 2004. Infection-related activation of the $c g 12$ promoter is conserved between actinorhizal and legume-rhizobia root nodule symbiosis. Plant Physiol. 136:3191-3197.

Sy, M. O., Constans, L., Obertello, M., Geney, C., Laplaze, L., Auguy, F., Hocher, V., Bogusz, D., and Franche, C. 2006. Analysis of the expression pattern conferred by the PsEnod $12 B$ promoter from the early nodulin gene of Pisum sativum in transgenic actinorhizal trees of the Casuarinaceae family. Plant Soil 281:281-289.

Vancanneyt, G., Schmidt, R., O'Connor-Sanchez, A., Willmitzer, L., and Rocha-Sosa, M. 1990. Construction of an intron-containing marker gene: Splicing of the intron in transgenic plants and its use in monitoring early events in Agrobacterium-mediated plant transformation. Mol. Gen. Genet. 220:245-250.

Vessey, J. K., Pawlowski, K., and Bergman, B. 2004. Root-based N2-fixing symbioses: Legumes, actinorhizal plants, Parasponia sp. and cycads. Plant Soil 266:205-230. 